\title{
Study on the Construction of Evaluation System for College Graduates' Entrepreneurship
}

\author{
(SUBMITTED BUT NOT PRESENTED)
}

\author{
CHEN Xiaodong \\ Chongqing Technology and Business University \\ China,Chongqing \\ Email:578462606@qq.com
}

\author{
ZHOU Li \\ Chongqing Technology and Business University \\ China,Chongqing \\ Email:1614208469@qq.com
}

\begin{abstract}
Entrepreneurship means the ability to discover or create a new field and to work on the creation of innovations. With different methods to utilize and develop the ability, one can make some new results come into being.Based on the connotation and characteristics of entrepreneurship, 3 first-class indexes, 9 second-class indexes and 8 third-class indexes are created. And the weight of these indexes has became an evaluation model for the entrepreneurship of college students, offering theoretical reference to the improvement of college students' entrepreneurship.
\end{abstract}

Key words-college graduates; entrepreneurship ; evaluation system

\section{INTRODUCTION}

The mass pioneering and innovation have been hot words in this year's Two Sessions which came to a close in March 2005. Among all those pioneers, the college students attract the most concern. Some statistics show that the number of college graduates was 2.8 million in 2004, respectively ju mping to 6.99 million and 7.27 million in 2013 and 2014, and it is estimated to be 7.49 million in 2015 . For the last ten years (from 2004 to 2014), China has seen a $160 \%$ increase in the number of college graduates. Now these constantly increasing graduates have caused the labor market the problem of oversupply. What's worse, the mis matching between talent cultivation in universities and social need even bring college students a bitterer situation caused by the pressure from employment.Against this background, it's a essential way to solve problems' of college students' employment by their breaking new ground that they should strengthen their awareness and ability to start an undertaking.

As the key impetus to boost innovation, employment and economic development, entrepreneurship is a must to guarantee the satisfaction of people's needs and the realization of individual values. China Youth News pointed that the proportion of self-employed college students is no more than $1 \%$, some relative statistics show, "however, this ratio rises to about $20 \%$ to $30 \%$ when it comes to some developed countries." As is seen to us, there still exist many problems in college graduates' entrepreneurship.

\section{THE CONNOTATION OF ENTREPRENEURSHIP}

In simple terms, entrepreneurship is the ability to succeed in business. Every entrepreneur eager to success, but it exists risk, and the entrepreneurship is directly related to the success of enterprise[1].Yu Yihong and Li Nengzhi (2000) argued that entrepreneurship means that under the certain conditions, one can find and capture opportunities to combine all kinds of resources to create greater value, that is to say one could well realize his entrepreneurial vision [2]. Gao Guijuan (2013) argues that entrepreneurship is the technical and the ability which could promote enterprises growth[3]. Therefore, entrepreneurship should be lived under a certain resources and environment condition, and the entrepreneurs need to make full use of their knowledge and experience and external resources to achieve success. Based on this, this paper holds the idea that entrepreneurship is the ability that the entrepreneur based on school family, and social education, find and capture opportunity, and utilize all kinds of recourses to create value.

\section{COLLEGE STUDENTS ENTREPRENEURSHIP} MODEL

\section{A. The Ideas Of Constructing Model}

Entrepreneurship is a comprehensive capabilities, using this system thoughts to build the college students entrepreneurship evaluation model. In terms of the elements selection, one should strictly accord to its systematicness, scientificity, comparability and maneuverability requirement selection[4], and under the condition of the external factors (economic and social development, family status, education curriculum, etc.) remained relatively stable,one should from the individual perspective select the variables factors which are affect college students' entrepreneurship[5] . The system can be divided into 3 first class indicators, 9 second class indicators and 8 third class indicators. Specific elements as follows (Figure.1):

According to elements which entrepreneurship constitution selected, this paper argues that College students Entrepreneurship can be defined as: $\mathrm{C}=\mathrm{F}(\mathrm{P}, \mathrm{R}, \mathrm{D})$. Where $\mathrm{C}$, $\mathrm{P}$, R, D respectively represent entrepreneurship, entrepreneurship source of power, analy zing decision-making power and overall resilience respectively, and $F$ represents for the constituting function of the College students entrepreneurship. 


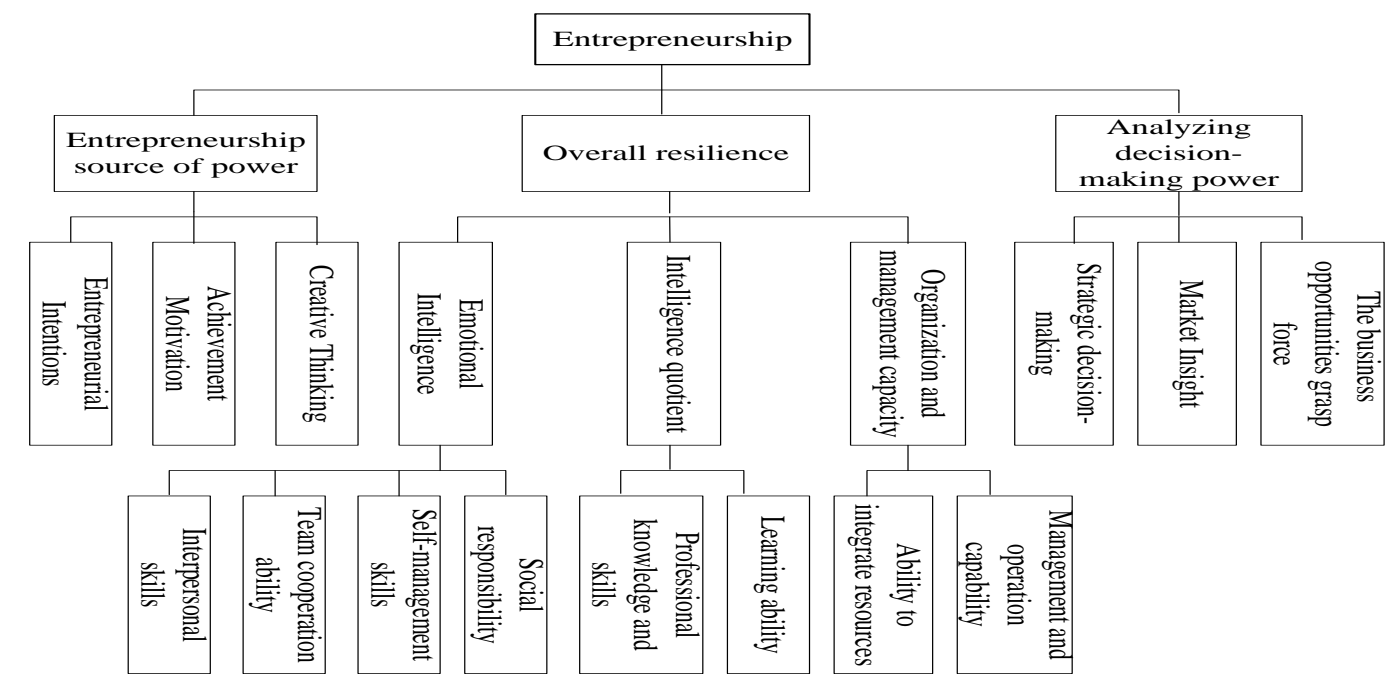

Fig.1. College Students Entrepreneurship Elements

\section{B. College Students Entrepreneurship Model Analysis}

\section{1) Entrepreneurship Source of Power}

For college students entrepreneurs, to start a business, first should process entrepreneurship source of power, and the entrepreneur intention, achievement motivation and innovative thinking are the main factors which related to the college students entrepreneurial source of power.

- The entrepreneur intention. The majority of entrepreneurial activities are planned rational behavior. Entrepreneurs intention is a subjective attitude of potential entrepreneurs for engaging in entrepreneurial activities or not, and is an extent similar to the characteristic of entrepreneurs as well as the general description of people's attitudes towards entrepreneurship. To strengthen the cultivation of the college students entrepreneur intention can provide mass base for the development of entrepreneurship education in colleges and universities, which is related to the cultivation of college students entrepreneurial quality, improving the college students' sensitivity for entrepreneurial opportunities.

- Achievement motivation. Achievement Motivation is closely related to the attitude of college students toward entrepreneurial activity, but also strongly correlation with the entrepreneur's family environment and social environment. The entrepreneurial motivations of college students can be divided into the need of survive, the need of accumulation, the need of selfrealization ,employment need and so on. Different achievement motivations may lead to different way to start. At the same time, education will affect the selection of entrepreneurs' entrepreneurial ways, such as higher educated entrepreneurs are opportunity orientated entrepreneurship, they tend to open up a career and seen it as a challenging job. While less educated entrepreneurs are necessity entrepreneurship, tend to get rich or meet the need of survival.

- Innovative thinking. The essence of creative thinking is to enhance the emotional desire to the rational exploration, to realize innovation activities from perceptual knowledge to rational thinking. People whose Innovative thinking are active tend to put innovative thinking into practice, to carry out entrepreneurial activities. At the same time, innovative thinking also plays an important role of entrepreneurial activity, to help entrepreneurs solve many problems during practice. Creative thinking is a kind of comprehensive, high-level thinking skills, and it is the most important ability factor for entrepreneurship.

2) Analyzing Decision-making Power

- Strategic decision-making power. In a fast-changing modern society, everyone must make multiple decisions every day. Decision-making is an important part of enterprise management, if one made wrong decision, all the links will be full of mistakes. Strategic decisions are affected by many internal and external factors, which require the entrepreneur to adjust corporate strategy to meet internal change, while also concerned about the changes in the external environment. To entrepreneurs, whether it is their own independent judgment or decision-making by the people after the discussion, they need to pay more attention to their ability of strategic decision-making.

- Market insight. Focus on the external environment is not simply to identify the external environment, but also have the ability to foresee the changes in the external environment, and according to changes in the external information effectively collected information to predict the change of enterprise operational environments, and then based on this prediction adjust their business direction. Market insight is closely related to the strategic decision-making, there is no good insight into the market it is impossible to make the right strategic decisions, initiative to change business ideas help companies seize the initiative in the fierce competition market.

- The ability to grasp opportunities.Entrepreneurship need your passion, entrepreneurship rely on your dream. However, a beautiful blueprint need a proper opportunity to make it come true. Grasping opportunities with market insight are consistent, without good insight into the market could not properly grasp the business opportunities. Firstly, correctly grasp the opportunity should pay more attention to the opportunity, then learn to take the initiative to create opportunities. However, university education is still mainly focus on explain the textbook knowledge, although there are a variety of college students entrepreneurship competitions and social practices can enhance their ability to grasp opportunities, and they still not enough to help students improve the capacity of business activities. So grasping business opportunity is a relatively weak link of college students in 
entrepreneurship, which requires students interested in entrepreneurship targeted to enhance their ability to grasp opportunities.

\section{3) The Overall Resilience}

- Emotional intelligence. EQ is a ability that a person to identify and monitor their own and others' feelings, proper maintenance of psychological adaptation and psychological balance, to form a self-motivated which is the core of the internal dynamic mechanism, to properly handle their own emotional, psychological quality, the relationship with others and personal development issues. For college students entrepreneurs, EQ quality mainly includes four aspects as follows: Interpersonal skills. The interpersonal relationship is bound to happen in the course of working, studying and business entrepreneurship. It is a common social phenomenon and a way of spiritual communication between people. Most of the successful entrepreneurs are good at communication with others, and good communication is one of the essential qualities of entrepreneurs. Interpersonal skills are critical for one to adapt to the environment and it's a very important capability in entrepreneurial process.Teamwork. Good teamwork ability is the necessary ability to mobilize all the resources and talents of team members, but also it is a good way to clear the phenomenon of disharmony and injustice. Normally, entrepreneurship could not complete by a person, but a team activity. If mutual cooperation among team members is from voluntary, it will produce a strong and long-lasting power.Selfmanagement skills. Good ability of self management requires entrepreneurs depend on their initiative, consciously and purposefully to transform and control their own thoughts and behavior. With good selfmanagement skills of entrepreneurs are more likely to have clear goals, self-awareness, effective learning and good planning, and these are rightly what entrepreneurs need to possess.Social responsibility. For entrepreneurs, not only need to master the necessary business knowledge, but also need to have professional ethics. Socially responsibility requires entrepreneurs to put the human interests, social interests and the interests of consumers in first place but not always pay attention to economic benefits. A strong sense of social responsibility not only helps entrepreneurs to succeed, but also is an important criterion to evaluating entrepreneurship efficiency.

- Intelligence Quotient. In a sense, intelligence is like computer hardware such as CPU, a high IQ people can do a lot of work in a short period of time. High IQ, wide knowledge and strong ability are the foundations for a person well survive in the society, but also are the basis qualities of entrepreneurial activity. The discussion of intelligence quotient in this paper includes the following two aspects:Professional knowledge and skills. Professional knowledge and skills contained two aspects intellectual skills and operational skills; it is manifestation of the actual working capacity and professional ability. For many years ago,people have paid great attention for professional knowledge and skills.,only with solid professional knowledge one can make his work more handy, and also can constantly to apply the knowledge into innovation. Learning ability. Learning ability is mainly on one's ability to accept new knowledge and things.In the process of college students' entrepreneurship, is bound to encounter all kinds of problems, and accept the information coming from every aspects,.Good learning ability can make the entrepreneurs found new enterprise development opportunities and direction, and promoting the growth of the enterprise.

- The organization and management capabilities. For the enterprise, organization and management capacity is the ability that the company's competitors under the same circumstances, with higher productivity or higher quality, and put various elements to translate them into product or service. It is the DNA for enterprises competition. Different organization and management capabilities will confine or strengthen business performance at different levels. In this paper, the author main ly from the aspects of resource integration and management ability to discuss the organizational management capabilities. Resource integration ability. The ability to integrate resources includes resources identification, acquisition, allocation and utilize four links. Entrepreneurial resources are scattered before integration, to maximize its effectiveness and create value for the enterprise., it needs start-up companies to use scientific methods to allocation of resources which could maximum utilization of resources. Management operational capability. The ability to integrate resources mainly focus on the resources that businesses need, while managing operational capacity is concerned with the healthy functioning of enterprises. Operations management is one of the most active branches of modern enterprise management science, which is closely related to products and services .

\section{Determination of the Weight and Index Values}

About the selection of assessment methods, index system usually use the methods of direct grade method, the weighted average , comprehensive index method, analytic hierarchy (AHP) and fuzzy theory of comprehensive evaluation methods, etc[6]. Various types of assessment methods have different characteristics, but in general it can be grouped into two categories: one is subjective weighting method, the other is an objective weighting method, the difference between the two methods lies in the different ways to determine the index weight. In assessing students' entrepreneurship usually use the ways of subjective weighting as follows: The primary index symbol is the entrepreneurial motivation $\left(X_{1}, P\right)$, analyzing decision-making power $\left(X_{2}, D\right)$, the overall resilience $\left(\mathrm{X}_{3}, \mathrm{R}\right)$. Secondary indicators of professional competence are entrepreneurial intentions $\left(\mathrm{x}_{1}\right)$, achievement motivation $\left(\mathrm{x}_{2}\right)$, innovative thinking $\left(\mathrm{x}_{3}\right)$. Secondary indicators of analyzing decision-making power include the strategic decision-making power $\left(\mathrm{x}_{4}\right)$, market insight $\left(\mathrm{x}_{5}\right)$, the ability to grasp opportunities $\left(\mathrm{x}_{6}\right)$. Secondary indicators of overall resilience are EQ $\left(\mathrm{x}_{7}\right)$, IQ $\left(\mathrm{x}_{8}\right)$, the organization and management capabilities $\left(\mathrm{x}_{9}\right)$. Three indicators of overall resilience are include the interpersonal interaction skills $\left(\mathrm{x}_{71}\right)$, team cooperation ability $\left(\mathrm{x}_{72}\right)$, social responsibility $\left(\mathrm{x}_{73}\right)$, professional knowledge and skills $\left(\mathrm{x}_{81}\right)$, learning ability $\left(\mathrm{x}_{82}\right)$, resource integration capability $\left(\mathrm{x}_{91}\right)$, management operational capacity $\left(\mathrm{x}_{92}\right)$. (Note: $\mathrm{A}, \mathrm{B}, \mathrm{C}$ as the weight of first grade indexes, $\mathrm{Xi}$ as the primary index symbol, xi as the secondary grade index symbol, xii as the third grade index symbol.) Then, the factors influencing college students' creativity can be divided into five grades that including outstanding, good, moderate, passing and poor. Criteria: scoring 90-100 as excellent, 80-89 as good, 70-79 as medium, 60-69 as passing, 60 points or less are poor.

\section{The Construction of Entrepreneurship Model}

Through the way of subjective weighting, using multivariate linear regression analysis build the model, $\mathrm{Y}=\mathrm{AX}_{1}+\mathrm{BX}_{2}+\mathrm{CX}_{3} \quad\left(0 \leq \mathrm{X}_{\mathrm{i}} \leq 100, \quad \mathrm{X}_{\mathrm{i}}=1, \quad 2,3\right)$; 
$\mathrm{X}_{1}=\mathrm{ax}_{1}+\mathrm{bx}_{2}+\mathrm{cx}_{3}, \mathrm{X}_{2}$ and $\mathrm{X}_{3}$ values and so on. When entrepreneurs start a program requires them to assess their situation objectively, to make a reasonable evaluation of capacity using the model of entrepreneurship indexes, and then according to the results of the evaluation are targeted improvement[7]. the model exist a defect about weight,the weight of model is set by the students subjective determination, every entrepreneur needs consideration according to the business environment and their own situation, therefore.

\section{CONCLUSIONS}

Entrepreneurship constitutes system is an interactive system, entrepreneurship source of power, analyzing decisionmaking power, the overall resilience are interactive and interdependence, together determine the advantages of college students, and its continue determined by the students' personal development.

To cultivate students' entrepreneurship, practical activities which could improve their subjective world is inseparable. Universities need to increase guidance in their practical activities and through holding high-quality business contest to encourage students to take participate in a variety of extracurricular activities to improve their ability.

Improving students' IQ and EQ have a great significant to enhance entrepreneurship. To improve IQ mainly depend on the textbook knowledge.To improve EQ needs the students' comprehensive understanding of themselves, fully affirm the advantages of their own, clearly realize their own shortcomings, properly handle interpersonal relationships and so on.

\section{ACKNOWLEDGEMENTS}

This paper is supported by the 2015 Bayu overseas program of introducing talents of Chongqing Technology and Business University and the research program on the teaching reform of colleges and Universities of Chongqing municipality supported by Chongqing Municipal Education Commission of China under grant 132036.

\section{REFERENCES}

[1] Chen Zhenhong, Liu Guoxin, Dong Junwu. Entrepreneurship Study Abroad's History 、 Dynamic and Trends[J].Foreign Social Science,2004,(1):21-27.

[2] Yu Yihong,Li Nengzhi. Entrepreneurship[M]. Shang Hai:Fudan Uniwersity Press, 2000 .

[3] Gao Guijuan,Su Yang.An Empirical Study of Entrepreneurial Competence of College Students:Construct and Concept [J].Higher Education Development and Evaluation, 2013(5):27-35.

[4] Xie Xiongbiao.Connotations and Ways to Enhance Entrepreneurial Force[J].Science and T echnology and Management ,2004(2):31-33.

[5] Yang Min.The way of Promoting College Students' Entrepreneurial Power Empirical Research[J]. Modern Shopping Mall,2009(31):97-98.

[6] Wang Xuming.Employment Force Model Construction of College Students[J].Higher Agricult ural Education, 201 1(4):89-93.

[7] $\mathrm{Hu}$ Guosheng.Construction of College Students Entrepreneurship Training System[J].Academic Forum,2009(5): 195-197. 